\title{
The Journal of Economics and Politics
}

Volume 24 | Issue 1

Article 1

2018

\section{The Politics of Passing and Implementing Medical Marijuana in Ohio}

\author{
A. Lee Hannah \\ Wright State University, lee.hannah@wright.edu
}

Follow this and additional works at: https:// collected.jcu.edu/jep

Part of the American Politics Commons

\section{Recommended Citation}

Hannah, A. Lee (2018) "The Politics of Passing and Implementing Medical Marijuana in Ohio," The Journal of Economics and Politics: Vol. 24 : Iss. 1 , Article 1.

Available at: https://collected.jcu.edu/jep/vol24/iss1/1

This Article is brought to you for free and open access by Carroll Collected. It has been accepted for inclusion in The Journal of Economics and Politics by an authorized editor of Carroll Collected. For more information, please contact connell@jcu.edu. 


\section{The Politics of Passing and Implementing Medical Marijuana in Ohio}

\section{Cover Page Footnote}

The author would like to thank Mandy Shannon, Daniel Mallinson, Christopher Ojeda, Amanda Parks, Eric Plutzer, Laura Bischoff, Kate Bell, Chris Lindsey, Erik Greathouse, and Jillian Hannah for thoughtful and helpful feedback and insights on the paper. The author is grateful for the anonymous reviewers and editor whose comments significantly improved the manuscript. 


\section{Introduction}

Ohio became the $25^{\text {th }}$ state to pass a medical marijuana law (MML) in June of 2016. The bill, HB523 , was passed with votes from members of both parties in Ohio's House and Senate. One might expect that this bill, with bipartisan support and the potential to create a multimillion-dollar industry in Ohio, would be trotted out by a proud governor. Instead, Governor John Kasich refrained from a signing ceremony and quietly signed HB-523 along with dozens of other bills(Borchardt, 2016c) This raises the question, why did Ohio pass an MML in 2016? And relatedly, how does Ohio's MML compare to other states?

The MML passed by Ohio's General Assembly is a prime example of how the threat of an initiative campaign can force legislative action from disinterested or recalcitrant lawmakers (Gerber, 1996). In the case of Ohio, direct democracy and shifting policy images forced action from reluctant legislators that had historically avoided the issue. And now, these same legislators are in charge of implementing the law.

I set out to describe how the adoption of Ohio's Medical Marijuana Control Program fits into broader patterns of policy diffusion and investigate how the law compares to other MMLs in the country. First, I review previous states' experiences with the adoption of MMLs and review the literature on policy diffusion. This theoretical context provides a basis for understanding how the Ohio MML came to be. Next, I use a recent dataset of MMLs to compare and contrast Ohio's law to others. Finally, using the latest research on medical cannabis and variation in MMLs across the country, I describe what to expect as HB-523 is implemented in the state.

This article contributes to the growing body of qualitative diffusion research (Starke, 2013) and integrates broader diffusion theories with the specific case of Ohio's MML. I test hypotheses and draw conclusions from the literature using statements by legislators during General Assembly proceedings, and interviews with five individuals with expert knowledge of medical marijuana policy and Ohio's law. ${ }^{1}$

\section{Mechanisms of Adoption: Direct Democracy and Shifting Policy Images}

\section{A. A Short History of Medical Marijuana Policy in the United States}

As of July 2018, thirty states and the District of Columbia have adopted MMLs (National Council of State Legislators [NCSL], 2018). The state of California adopted the first medical marijuana law in 1996 through voter initiative.

There is some confusion related to what qualifies as an MML. Several organizations including nonpartisan groups like the National Conference of State Legislatures [NCSL] and ProCon.org, and interest groups such as Americans for Safe Access [ASA] and Marijuana Policy Project [MPP] define MMLs as those that "allow for comprehensive public marijuana and cannabis programs." Laws are identified as "comprehensive" if they meet the following criteria:

1) protection from criminal penalties for using marijuana for a medical purpose; 2) access to marijuana through home cultivation, dispensaries, or some other system that is likely to be implemented; 3) it allows a variety of strains, including those more than "low THC" or cannabinoid 
oils; and 4) it allows either smoking or vaporization of some kind of marijuana products, plant material or extract. ${ }^{3}$ (NCSL, 2018)

Therefore, a number of states that have passed limited access marijuana programs (e.g., Alabama, Georgia, Kentucky, and 13 other states) are not considered MML states. Figure 1 displays the states that have passed MMLs - with colors denoting the years when the state adopted. The map shows that the earliest adoptions primarily occurred on the West Coast and Mountain West. Over time, the majority of states in the Northeast adopted MMLs. The most recent adopters (depicted in light brown) are more regionally scattered than previous adopters.

\section{B. Policy Diffusion}

Scholars have studied the diffusion patterns of public policies in the states (F. S. Berry \& Berry, 1990; Gray, 1973; Karch, 2007; Walker, 1969). Diffusion research has focused on four broad mechanisms to explain the spread of policies: learning, imitation, competition, and coercion (Volden, 2017). Policy learning occurs when states observe the actions of other states, and if successful, adopt the policies as their own. Learning occurs in marijuana policy in two ways. First, states have learned that the federal government has largely stayed out of the industry. Second, states learn from best practices of previous adopters. Imitation occurs when a state adopts another law without considering its effectiveness. This is an unlikely mechanism in the diffusion of MMLs, as the creation of a program is costly and risks inciting federal action.

Competition describes the process whereby states compete with proximate states for resources, tax revenue, and potential jobs (W. D. Berry \& Baybeck, 2005; Boehmke \& Witmer, 2004). While much has been written about the revenue windfalls from tax dollars collected in recreational states, there is less evidence of such profits in MML states. However, legislators and voters in recent adopting states have been more receptive of market-related appeals and the fact that entrepreneurs can create jobs and a small tax base. But, as one local reporter observes, "I think they've [Ohio's state legislators] been mindful of the optics of setting up a 'medical' system and then taxing the heck out of it to gin up money for the state coffers" (IV 2, personal communication, February 28, 2018). Finally, coercion describes the diffusion process that occurs when states face top-down pressures from the federal government through regulations and intergovernmental grants. Coercion has been a common mechanism to shape education, environmental and health policy in the twenty-first century. However, marijuana policy works in the opposite direction, whereby federal policy prohibits the use of medical cannabis. In the diffusion literature, each of these concepts have been tested by a number of state-level features that scholars have found to be important such as slack resources and state capacity, ideology, fiscal health, neighbor adoption, and so on. This has led to a rich and empirically-based body of research on the diffusion of a number of laws, including MMLs.

Recent research by Hannah and Mallinson (2018) has demonstrated that the diffusion of MMLs spread in more liberal and less religious states, was aided by the direct initiative, and followed a pattern of ideological, rather than regional, diffusion. Surprisingly, they found little evidence that states were thwarted by actions from the federal government (Hannah \& Mallinson, 2018). But as Karch (2007) notes, such broad studies have limitations. 
As such, diffusion is not merely an increase of usage or incidence of a policy or form, but rather the result of a dynamic decisionmaking process. Therefore, we must look beneath the aggregatelevel data so often used in such research to understand the individual-level decisionmaking that drives state policy diffusion (Karch 2007, p.56).

For this reason, it is important to provide a richer description of the adoption process in Ohio in order to illuminate how these broader diffusion processes transpired in one state. I do so by synthesizing local reporting on the topic, recording deliberations in the Ohio General Assembly, and interviewing individuals who were involved in the process (see appendix) including a consultant for the Issue 3 campaign and current industry lobbyist (IV 3), 2 legal counsels for a major pro-marijuana liberalization interest group (IV1 and IV4), a reporter for a regional paper in Ohio (IV 2), and the director of a pro-medical marijuana interest group (IV 5).

In the next two sections, I discuss how the political landscape changed in Ohio - providing a window for policy entrepreneurs to engage and legislators to feel pressure to act. Using interviews and statements from legislators, I show that direct democracy compelled legislators and the governor to act. This action, in turn, was aided by the reframing of the issue. I show how this reframing occurred by analyzing newspaper content.

\section{Direct Democracy and Policy Diffusion in Ohio}

Direct democracy helped push Ohio's legislature to adopt an MML in two ways. First, the proposal of Issue 3 in 2015 opened up a "policy window" (Kingdon, 1995). As Kingdon (1995) argues, policy windows can open as a result of a pressing problem or focusing event; but they can also open by changes in the political stream. In particular, advocates used an initiative campaign to put marijuana policy on the agenda, elevating a discussion of the topic that had garnered little attention historically in the state. Second, a looming initiative proposal by MPP further pressured legislators to seriously consider adopting an MML.

Hypothesis 1: Ohio legislators' adoption of an MML was motivated by the threat of an initiative.

Scholars have investigated whether direct democracy institutions produce laws that are responsive to public demand. About half of the states allow for a direct initiative to be placed on the ballot from outside groups. In states without direct democracy, voters have little opportunity to challenge their legislators outside of primary and general elections. But in states with direct democracy, the initiative provides voters with an alternative mechanism to both set the policy agenda and enact legislation (Phillips, 2008). Thus, direct democracy in states can lead to policies that are closer to the median voter on a number of specific policies including abortion policy (Gerber, 1996), tax policy (Phillips, 2008), and gay rights (Lax \& Phillips, 2009). Moreover, there is evidence that states with initiatives produce policy that is broadly more congruent with voter preferences (Arceneaux, 2002; Gerber, 1999; Lascher \& Hagen, 1996; Lupia \& Matsusaka, 2004; Matsusaka, 2004, 2014). Direct democracy affects policy through direct effects (i.e. passed laws) and indirect effects (i.e. the threat of an initiative that forces legislators to produce more congruent policies).

In the case of MMLs, there is evidence that the initiative has had both direct and indirect effects on the passage of policy. For example, due to the broad lack of support from elected officials, the vast majority of MMLs adopted in the first ten years were done so by ballot initiatives (80\%) with 
legislatures adopting MMLs sparingly and only in fairly liberal states (Hawaii in 2000, Vermont in 2004, Rhode Island in 2006). Early on, even sympathetic legislators may have been hesitant to use their political capital on a polarizing issue. In fact, the first five initiatives (passed in 1996 and 1998) passed with less than 60 percent of the vote. ${ }^{4}$ Analyzing the adoption of MMLs through 2014, Hannah and Mallinson (2018) found that states with direct democracy were three times as likely to adopt an MML, even after controlling for states' ideology, evangelical population, and neighbor adoptions.

In the 2015 general election, ResponsibleOhio poured over twenty million dollars into Issue 3 - a measure that would have legalized recreational and medical marijuana (Borchardt, 2015). The campaign itself was flawed in a number of ways, most notably, the initiative would have written a monopoly of production into Ohio's constitution. To combat the problematic and poorly written initiative, the Ohio legislature placed another amendment on the ballot, Issue 2, that would have allowed the Ohio Ballot Board to regulate monopolies and consequently strike down Issue 3 if it passed (Whyte, 2015). Issue 3 not only faced resistance from the legislature. The flaws in the initiative led even the Drug Policy Alliance and MPP to withhold endorsements (Graham, 2015).

Even though the initiative was voted down by a 2 to 1 margin, the campaign environment and polling revealed that the vast majority of Ohioans supported a medical marijuana program (Higgs, 2015). Consequently, in 2016, Ohioans for Medical Marijuana started gathering signatures for a medical marijuana ballot initiative. This organization had the backing of Marijuana Policy Project, considered by many to be the "adult in the room" (Borchardt, 2016a). At this point. the legislature acted at an "astonishing" pace to write an MML on its own terms (Sandy, 2017).

Two individuals that worked closely on marijuana policy in Ohio confirm the notion that the threat of an initiative altered the agenda in Ohio. A legislative counsel with a pro-marijuana interest group stated, "The first thing that I recall from Ohio was that there was no chance of medical marijuana passing at the legislative level" (IV 1, personal communication, February 28, 2018). This sentiment was shared by a consultant who worked on ResponsibleOhio's Issue 3 campaign. "Every year we would propose [an MML] and would never get a committee hearing. Suddenly, [Governor] Kasich's folks and others were in communication within weeks of the failed initiative [Issue 3]" (IV 3, personal communication, March 6, 2018). Both sources cite a rapid and unexpected shift in the interest of lawmakers.

Therefore, when Ohio House members first began taking up legislation in committee, many in the pro-marijuana interest community did not anticipate that the legislators would be able to produce a bill. Early on in 2016, law makers worked independently, but soon invited others to the table for guidance. As the law evolved, legislators "deferred a lot of heavy lifting on the agencies" (IV 1). This feature was most critical in causing MPP to abandon its initiative campaign. MPP had an opportunity along with other interest groups and state leaders to aid the agencies in rulemaking procedures, and decided to expend resources in those efforts rather than on an expensive initiative campaign.

In speeches in the Ohio General Assembly, ${ }^{5}$ numerous legislators alluded to the threat of an initiative as reason to adopt HB-523. In Senate proceedings, Sen. David Burke (R - Marysville) argued, 
Each one of us, regardless of how we vote on this piece legislation, I know reflect the will of our districts, and the people that sent us here. That does not occur in a ballot initiative. And worse, a ballot initiative can't change. And the ballot initiative that occurred in Issue 3, and may arise in November, totally excludes the General Assembly from any changes. I hope it's perfect if that's the route people go. (Ohio Senate, 2016, Third Consideration Hearing for H.B. 523, $131^{\text {st }}$ General Assembly $2^{\text {nd }}$ sess., May 24)

Meanwhile, in the Ohio House of Representatives, Rep. Kirk Schuring ( $\mathrm{R}$ - Canton) indicated that the legislature was at risk of losing control over the creation of a medical marijuana program.

Those who came in and testified as opponents, he [Chair of House Health Committee, Rep. Steve Huffman] always asked the question, "Well, given the situation, would you rather have the General Assembly take control of this issue? Or would you rather have outsiders chisel something in to our constitution?" And without exception, they said they'd rather have the legislature take control of this, take the lead. And that's what we're doing. (Ohio House, 2016, Third Consideration Hearing for H.B. $523,131^{\text {st }}$ General Assembly $2^{\text {nd }}$ sess., May 10)

Representative Tim Brown ( $\mathrm{R}$ - Bowling Green) made a similar argument while encouraging his colleagues to vote on HB-523.

But if we have missed something, if the science advances, we need to come back and adjust the language, or roll something back, or expand in some area. Because we've had the courage to do this legislatively, rather than what was proposed to our citizens last November, we can fix it. We can alter it. And we can change it because it is a law, that we had the courage to step up and vote to support. (Ohio House, 2016, Third Consideration Hearing for H.B. 523, $131^{\text {st }}$ General Assembly $2^{\text {nd }}$ sess., May 10)

There was a surprising amount of self-congratulatory speech in both chambers. Representative Teresa Fedor (D - Toledo) was not convinced that her colleagues had acted with such courage or sincerity. In stating her opposition to the bill, primarily over its lack of employment protections for patients, she goes a step further to call out many of the legislators for their disingenuous interest in the policy.

Kudos to all of those folks who've come a long way. Because I do remember two years ago, that most of us gave Representative Bob Hagan a belly laugh when he had an amendment, you know, that we thought made sense. And I know many of the legislators who had prior bills in both House and Senate and it was brave of those leaders to even have a hearing on the issue back then. So, we've come a long way... For that reason, and some others, you know, legislators only want to congratulate themselves when they can only go as far as they can. Because the politics won't let them go any further.... So, you can congratulate yourselves all that you want... But this is a cruel joke when citizens find out that they have to leave Ohio to get a job. (Ohio House, 2016, Third Consideration Hearing for H.B. 523, $131^{\text {st }}$ General Assembly $2^{\text {nd }}$ sess., May 10)

These comments suggest that proponents and opponents agreed that direct democracy had altered the political environment. 


\section{Shifting Policy Images}

The diffusion of medical marijuana to Ohio was also aided by shifting policy images around the issue. Baumgartner and Jones (2009) define policy images as "how a policy is understood and discussed...policy images are always a mixture of empirical information and emotive appeals" ( $p$. 25-6). The policy images around medical marijuana policy changed over time and in ways that made the policy more palatable to be taken up by socially conservative states.

For example, when California was considering legalizing medical marijuana in 1996, California Governor Pete Wilson and Senator Dianne Feinstein, along with presidential candidates from both parties denounced the initiative. General Barry R. McCaffrey, President Clinton's drug policy advisor, argued that California's 1996 medical marijuana initiative was a "stalking horse for legalization." He further dismissed the law by arguing, "[W]e should ask ourselves if we really want Cheech and Chong logic to guide our thinking about medicine" (Goldberg, 1996). This was a typical characterization of medical cannabis in the early years of adoption.

Proponents of medical cannabis fought back by constructing positive and sympathetic images of beneficiaries of the policy. Public officials are more likely to be pressured to act on a policy when the recipients of that policy are positively constructed (Schneider \& Ingram, 1993). The move to pass an MML in California was led by gay rights activists such as Dennis Peron and Robert C. Randall, mobilized by the AIDS epidemic and the palliative effects of marijuana. That is not to say that other conditions like cancer were ignored - but gay rights activists led the way (Werner, 2001). Schneider and Ingram (1993) write, “[P]olicy sends messages about what government is supposed to do, which citizens are deserving (and which not), and what kinds of attitudes and participatory patterns are appropriate in a democratic society" (p.334). In a federal structure, the definition of deserving and undeserving citizens varies by state; therefore, it's unsurprising that the first MML adoptions came in socially liberal states.

Shifting frames aided in expanding medical marijuana laws to more socially conservative states. In particular, research related to the effects of medical cannabis on PTSD (Bonn-Miller, Babson, \& Vandrey, 2014), epilepsy (Devinsky et al., 2014; Maa \& Figi, 2014), and opiate abuse (Bachhuber, Saloner, Cunningham, \& Barry, 2014; Shi, 2017) allowed for legislators and policy entrepreneurs to redefine the policy with these frames in mind. Not only have medical marijuana advocacy organizations changed their framing of the issue, they have also partnered with other organizations that work closely with patients of these conditions (IV5, personal communication, March 22, 2018).

In order to determine whether or not the policy images around medical cannabis have changed in the public domain, I search newspapers for the frequency of mentions of medical marijuana with these specific health conditions. Molotch and Lester (1975) argue that news "is a function, not of the nature of the world 'out there,', but of the work of those who must somehow bring into being some things which are more important than others" (p. 236). The way in which journalists cover MMLs can show how the broader understanding of the policy is changing over time. I include cancer in the search with the expectation that mentions of cancer is constant - both in its association with medical cannabis and in its frequency of diagnoses. 
The change in frames around the issue sets up my next two hypotheses. While there are a number of ways to approach how a topic is framed - I focus on the shifting emphasis of qualifying conditions. That is, appeals made to the public, and covered by the media, will shift over time. In particular, these shifts will be made strategically to highlight the most sympathetic of conditions and potential patients and to highlight issues most salient to national and state and local interests.

Hypothesis 2: Policy images related to medical marijuana shift over time, from emphasizing AIDS and HIV to discussing conditions that recent research has connected to medical marijuana.

Hypothesis 3: Policy images related to medical marijuana in local coverage are more likely to mention the opioid crisis than other conditions.

I retrieved articles for analysis using a Lexis Nexis keyword search for "medical marijuana" and specific health conditions including: Cancer, HIV/AIDS, epilepsy, PTSD, traumatic brain injuries, and opioids (see Table 1). The search is set up to return articles that included medical marijuana in the headline or lead along with the specified medical condition.

Figure 2 displays the number of mentions of each of these conditions over time in the New York Times (NYT). For comparison, I ran identical searches in the Washington Post to show the results are similar to the $N Y T$ (see Figure A1 in the appendix).

It is important to note that the articles are not mutually exclusive. Articles that include multiple diagnoses are frequently double-counted in the analysis. But this feature should give strength to the measure. That is, the news content results do not just indicate an ever-growing list of qualifying conditions, rather many of these articles do not include conditions historically connected to medical cannabis and instead focus on new conditions. Journalists are making a conscious choice to elevate some conditions over others.

Figure 2 shows how the framing of medical marijuana policy has evolved. In particular, there is an uptick in attention to post-traumatic stress disorder, associated with veterans suffering from the effects of PTSD from the wars in Iraq and Afghanistan (Jonsson, 2018). And there is increased frequency of articles that mention epilepsy, a change borne largely out of the efforts of the "mommy lobby" and new research related to the effect cannabinoid oils can have on mitigating seizures (Cha, 2014; Maa \& Figi, 2014; Pickert, 2014). Finally, the opioid crisis, and the exponential increase in heroin use starting around 2010, has garnered more attention in news coverage of medical marijuana (Wilkerson, Kim, Windsor, \& Mareiniss, 2016). As expected, mentions of cancer are prominent throughout the analysis. Even though there are a number of journalists and medical professionals that argue these connections are overhyped (Hall et al., 2018; Lopez, 2018), currently more coverage is given to the potential of medical cannabis to allay these public health concerns.

To test my next hypothesis, I retrieve articles from The Dayton Daily News (DDN). ${ }^{6}$ By the time Ohio takes up the policy, the opioid epidemic is a prominent issue in the state's politics. Journalists in Ohio would be motivated to only cover medical marijuana when it becomes a serious proposition, and also do so in a way that is most relevant to their readership. Figure 3 shows the trends in $D D N$ coverage of medical marijuana from 1995 to 2017. 
The results from the $D D N$ confirm the hypothesis that the opioid epidemic is prominent in medical marijuana news coverage. However, it is surprising that cancer is mentioned at a much higher rate - 15 times in both 2016 and 2017. Moreover, AIDS and epilepsy are both mentioned more than PTSD - a surprising trend given Dayton's military population. The search also shows that medical marijuana was rarely mentioned prior to the policy becoming a statewide issue - consistent with differences in national and regional coverage (Birkland \& Waterman, 2008).

While I could not replicate the same analysis in other publications, there is evidence that other regional Ohio papers emphasized these same themes. As the law was arriving on Governor Kasich's desk, the Cincinnati Enquirer published a long profile on a mother, a veteran, and a woman with chronic pain (Balmert, 2016a). Meanwhile, the Toledo Blade ran a similar profile in an article titled "Area patients praise medical marijuana benefits" that focused on a mother of a child with Dravet syndrome, a nurse dealing with chronic pain from an accident, and a retired police officer who questioned the efficacy of marijuana enforcement (Henry, 2016). Finally, the Plain Dealer ran an article titled "Could medical marijuana solve Ohio's opioid problem?" (Borchardt, 2016b). ${ }^{7}$

The newspaper content analysis shows that frames related to medical cannabis have changed over time. What cannot be teased out is the causal mechanism. The trend is likely explained by a combination of the changing way journalists view the issue, economic pressures to discuss policies in terms most relevant to readers, and shifting strategies from advocates and lawmakers to frame the issue in the most salient and compassionate ways.

Consider how Senator Kenny Yuko (D-Youngstown) discussed the issue on the Senate floor:

Well a person my age, when you heard of marijuana back in those days, back in 2003, When I heard two words associated with marijuana, it wasn't 'medical' and 'marijuana'. It was more like 'Cheech' and 'Chong', 'Snoop' and 'Dog', and 'Willie' and 'Nelson'... The reality of it is, once I did a little research, I found out how wrong I was...This bill is not perfect folks, but it's what Ohio patient [sic] needs. It's not acceptable to make them wait any longer. If we can give just one veteran comfort, if we can ease one patient's horrible pain, if we can maybe improve or even save a child's life, this bill will be worth it. (Ohio Senate, 2016, Third Consideration Hearing for H.B. 523, $131^{\text {st }}$ General Assembly $2^{\text {nd }}$ sess., May 24)

The analysis so far has shown how direct democracy and shifting frames are important factors in the diffusion of medical cannabis to Ohio. I have demonstrated the face validity to this narrative through evidence from the literature, interviews, and an analysis of newspaper coverage. But if the adoption of this law required institutional and political pressures, does the actual content of the law differ from prior adopters? Such analysis has been a limitation with many studies of diffusion. Graham, Shipan, and Volden (2013) observe:

Even when one focuses solely on the spread of public policies, however, diffusion studies tend to ignore a wide range of relevant questions, including how ideas find their way onto the agenda, how agenda items become laws, whether laws are just ideas until an implementer turns them into actual policies, and so on. This emphasis on stages of the policy process has long been central to public policy, yet the diffusion literature sets aside the early and later stages of the policy making process and focuses almost exclusively on the adoption stage. (p. 689) 
This is not the first appeal for diffusion research to address individual behaviors, implementation, and the content of laws. Andrew Karch (2007b) notes this criticism of diffusion research is brought up frequently, but rarely addressed. Karch (2007b) calls for an emphasis on "What is being diffused", as he notes, "Ignoring the question of policy content, as most state policy diffusion research has done, fails to address an important aspect of variation across space and time that has both theoretical and practical implications" (p. 69).

In the next section, I compare and contrast Ohio's MML with other state MMLs. I find that Ohio's law is consistent with some trends of recent adopting states, particularly with regards to expanding the qualifying conditions but limiting personal cultivation and smoking. With regard to these features, the content of Ohio's law is best explained by temporal trends rather than ideological ones. The law lists more qualifying conditions than the majority of states, but has been criticized for its lack of employment protections.

\section{What is in Ohio's Law?}

\section{A. Variation in Language in MML Laws}

As MMLs have been adopted by more states, scholars have started to investigate the heterogeneity of these laws (Chapman, Spetz, Lin, Chan, \& Schmidt, 2016; Klieger et al., 2017; Pacula, Powell, Heaton, \& Sevigny, 2014; Pacula \& Sevigny, 2014). Legislatures creating MMLs have to account for a number of factors governing patients, caretakers, doctors, law enforcement, prosecutors, producers, and entrepreneurs.

Understanding these differences in the content of MMLs is important for policy analysis. Thus far, the majority of research treats the features of an MML as an independent variable predicting a public health outcome as the dependent variable. For example, studies have shown that MMLs are associated with a decrease in painkiller overdoses (Bachhuber et al., 2014), fewer hospitalizations due to opiates (Shi, 2017), decreased prescriptions and spending in Medicare Part D (Bradford \& Bradford, 2016), and fewer fatal car accidents due to opiates among 21-40 year-olds (Kim et al., 2016). Scholars have just started to explore the nuance of the laws and some have challenged the conclusions of the aforementioned studies (Hall et al., 2018).

To better understand how Ohio's MML compares to others, I use data from the Prescription Drug Abuse Policy System (http://www.pdaps.org) on MMLs created by Klieger and colleagues (2017). Two legal researchers coded each of the twenty-eight MMLs as they existed in 2017 and created three empirical data sets. ${ }^{8}$ The three datasets focus on state laws governing marijuana patients (coded for all states), product safety (coded for 22 states that include such provisions) ${ }^{9}$, and dispensaries (coded for 25 states); each dataset contains binary indicators of whether a state's law does or does not contain a provision.

\section{B. Ohio's Medical Marijuana Control Program in Context}

Laws in every state have listed qualifying conditions in their MMLs. Figure 4 displays the number of qualifying conditions listed in each state law plotted over the year in which the state passed the law and shows a trend of states including more conditions over time. This is evident in Ohio's law, which lists more qualifying conditions (16) than all but two states. Ohio's MML is one of a 
minority of states that includes traumatic brain injuries, inflammatory bowel disease, Tourette's syndrome, and Alzheimer's disease. Ohio's law, along with 21 other states (79\%), also includes a provision for adding to the list of qualified conditions.

Many of the early states to adopt an MML did not include patient registries. After federal guidance in 2009 (Ogden, 2009), all states except for Florida and Minnesota require patient registries. The Ohio Medical Marijuana Control Program finalized guidelines and rules in September of 2017, but the registry has yet to be opened to patients. ${ }^{10}$

When Ohio legislators took charge in writing their own law, MPP was in the midst of a signature gathering campaign for their own initiative to appear on the 2016 ballot. Though eventually dropped, MPP's campaign for an initiative that would have differed in two critical ways from the law that was passed in the legislature. It would have allowed for home cultivation and for smoking marijuana. Republican State Sen. David Burke, a co-sponsor of the bill, told reporters, "Smoking dope and growing dope, that's not an Ohio thing" (Balmert, 2016b). "Smoking is a boogie man for lawmakers" (IV1). Law makers are careful to write laws that do not alert fears of de facto recreational marijuana, so smoking has become increasingly scrutinized as inconsistent with other medications. Advocacy groups have conceded on smoking, as long as some form of vaporizing is an option as some conditions require a rapid onset delivery in order to provide pain relief (IV1). The restriction of smoking is common in recent state laws (NY, MN, FL, PA).

The program also sets limitations on home cultivation. On this point, Ohio's MML is part of a growing trend. Of the eighteen states that have adopted or modified MMLs since 2010, all but five have restricted home cultivation (72\%). The five states that do allow home cultivation have all passed the law via initiative. Twelve of the thirteen states that do not allow home cultivation passed MMLs in the legislature (Klieger et al., 2017). ${ }^{11}$ But this trend has some downsides according to a legal counsel with a pro-marijuana interest group. In particular, some states have been reluctant to provide dispensary licenses, making the state-controlled market small and often vertically integrated, driving up prices (IV4, personal communication, March 9, 2018). Moreover, potential patients are dependent on the state to get the program up and running.

Ohio's law fits the depiction of a "medicalized" program (A. R. Williams, Olfson, Kim, Martins, \& Kleber, 2016). Williams and colleagues (2016) examined the first twenty-four medical marijuana laws "according to seven components of traditional medical care and pharmaceutical regulation" ( $\mathrm{p}$. 480). They determined that fourteen of the twenty-four programs were "nonmedical" and contained few regulations. Next, they compared patient enrollment in medicalized and nonmedical programs. They determined that over 99 percent of nationwide enrollment in medical marijuana programs occurred in nonmedical states. In general, the nonmedical programs were older (10 years on average) and in the West (all 10 programs in the region are labeled nonmedical).

Table 2 displays the features of MMLs organized by region. Most of the earliest adopting states are located in the West, adopted via direct democracy, and contain programs that are nonmedical. As the policy has evolved and spread to other regions, it has become increasingly medicalized. Thus, one can expect that the medicalized nature of these laws will also affect implementation. 
One of the most significant criticisms of the law has been related to provisions that protect employers. While Ohio received a passing mark from Americans for Safe Access (2017), the medical cannabis advocacy organization also notes:

If Ohio can move through the implementation in a timely manner and adopt strong product safety protocols it could be one of the stronger programs in the country. However, the medical cannabis law includes the worst employment language in the country for patients, making employment discrimination against patients lawful and explicitly denies patients a cause of action in court to challenge employment discrimination cases. (p. 137)

In House proceedings, Rep. Teresa Fedor ( $\mathrm{D}$ - Toledo) spoke in opposition to the bill primarily for the employment language. Describing the catch-22 that patients would face, Rep. Fedor argued, "[S]o go ahead and use medical marijuana, but you'll be discriminated against when you are well enough to get a job" (Ohio House, 2016, Third Consideration Hearing for H.B. 523, $131^{\text {st }}$ General Assembly $2^{\text {nd }}$ sess., May 10). Employers are given broad discretion in how they treat medical marijuana patients. They can use drug tests to screen job candidates, prohibit medical use, and discipline workers for cannabis use. Moreover, workers fired for marijuana-use will not have access to unemployment benefits or workers' compensation. The discretion does cut both ways, as employers are also allowed to set different standards based on the mental and physical demands of the job (M. Williams, 2018).

\section{Implementing Medical Marijuana in Ohio}

\section{A. The Regulatory Environment}

The process of implementing Ohio's medical marijuana law is still developing. Not unlike other programs, the program has faced a number of delays and failed to open on its targeted implementation date of September 8, 2018. The best way to understand the implementation is to examine six key areas: Cultivation, processing, testing, dispensaries, physicians and patients. Physicians and patients are listed last. Since the law does not permit home growth and cultivation, physicians and patients are dependent on the development of the industry (Borchardt, 2018; Simmons, 2018).

While the state may be prepared to serve patients, the supply of cannabis is bogged down in regulation. In fact, Grant Miller, a spokesman for the pharmacy board, recently commented on the delay in rolling out the patient registry, "The registry has been tested, and we're confident in its functionality and usage. It basically just has to be turned on. Whenever we have a date, we'll be ready" (Tucker, 2018b). The number of potential patients is unknown, although 185 Ohio doctors have obtained a "certificate to recommend" (CTR) on their medical license (Simmons, 2018).

Figure 5 displays details and the latest status (as of July 2018) related to the cultivation, processing, testing, and dispensaries process in Ohio. The figure shows the process medical cannabis must go through before patients have access and each step is dependent on the previous one. With the state only recently approving the first cultivator to start planting; processors, testing labs, and dispensaries are left waiting. These delays are largely due to the regulatory environment and local politics. As one interviewee put it, "whenever you create a multimillion- 
dollar policy, there's going to be issues" (IV 3). They continued, "[I]t's clear that the state did not hire enough graders. [The] Department of Commerce did not have enough staff and manpower. They didn't have malice or intend to drag their feet, but they weren't enthusiastic either" (IV 3). The lack of graders (and background of one) and lack of transparency about the process have led to a series of lawsuits and contributed to the delays (Bischoff, 2017; Tucker, 2018a).

\section{B. Local Control}

While localities cannot prohibit patients or physicians to use or prescribe medical cannabis, they can restrict cultivators, processing facilities, and dispensaries from operating in their boundaries. Many localities moved to pass bans or moratoriums on the marijuana industry drew heightened interest from citizens concerned about expanding marijuana into their backyard. This added uncertainty for industries trying to move into Ohio as they had to navigate state regulations while also negotiating with local communities over property and zoning rules (Knox, 2017).

For example, Beavercreek's city council passed a six-month ban on the industry in January of 2018. However, a company applied for a dispensary license in Beavercreek prior to the ban and was awarded a state license in June. This has led to major debates about whether the township will set a ban, likely facing a lawsuit, or work with the one dispensary but limit expansion (Wilson, 2018).

But, other localities have lifted moratoriums, motivated by potential tax revenue and jobs. A councilman regretted passing a moratorium in Lima, arguing "We need to keep ourselves in the game" (Ellerbrock, 2018). The city of Cleveland lifted a year-long moratorium, with some citing the fact that Boston added millions of tax revenue after Massachusetts passed a similar program (Higgs, 2015).

The concerns that have come up in communities have varied. For example, in Marietta, citizens voiced concerns over an approved dispensary's location near a busy intersection and its proximity to a stadium that is used by local high schools (Patterson, 2018). Due to federal regulations, the marijuana industry runs on a largely cash-based system - citizens in Dayton expressed fear that the industry would attract crime (Stewart, 2018). In Marion, council members feared added foot traffic downtown and the pressure it would put on a cash-strapped police force (Volpenhein, 2017). But, in Gibsonburg (Sandusky County), the police chief supported medical marijuana, arguing it could help with the opioid epidemic. He went on to discuss the potential economic benefits. "First, it's a new business in Gibsonburg and in the county, and we can't police without tax money" (Shoup, 2018).

In summary, the regulatory environment combined with local ordinances have delayed the implementation of the program. This is not uncommon. Given the complexity of regulating a newly created program and the federal government's ambiguous position, many state programs have taken years to get off the ground (Breitenbach, 2015). 


\section{Concluding Remarks}

This paper sheds light on the adoption process of an MML in Ohio and on the structure of the law. Passing an MML in Ohio required a transformation of the political landscape. A looming initiative campaign combined with shifting policy images motivated legislators in Ohio to adopt an MML. Legislators created a law consistent with recent adopters, but also included provisions that were most palatable to their constituents, particularly in terms of prohibitions on cultivation and smoking, employer protections and local control. And now, politics will shape the implementation of the law.

Questions remain about how the law will ultimately be implemented. One of the most common arguments for passing the law in the legislature, and not by initiative, was that legislators would be able to maintain control over a program that they developed. This feature could lead to two different outcomes. On the one hand, the legislature has the flexibility and statutory authority to monitor implementation and make improvements to the program and law. On the other hand, elected leaders in Ohio might know that they did just enough to thwart an initiative campaign, but be less devoted to the implementation of the law. Moreover, the environment could completely change if a recreational marijuana initiative, scheduled for the 2019 election, makes the ballot and gets approved (Garbe \& Bischoff, 2018).

New Jersey provides an instructive case for how politics affect the implementation of an MML. The New Jersey legislature passed an MML in 2009 that outgoing Democratic Governor Jon Corzine signed in January of 2010, on his last day in office (Heininger, 2010). Republican Governor Chris Christie remained skeptical of the program for his entire term, and the program was largely viewed as untenable for doctors, patients, or providers (Johnson, 2014). As a consequence, the program remained small. For example, New Jersey and Michigan are similarly sized states that passed programs around the same time; at the start of 2018, New Jersey had 15,000 card-holding members in its program compared to 220,000 members in Michigan (Livio, 2018). As Democratic Governor Phil Murphy took office in 2018, he tasked the Department of Health with making a workable law and prioritized medical access to marijuana (IV4, personal communication, March 9, 2018). After four months in office, the patient registry doubled (Nash, 2018).

The future of medical marijuana policy in Ohio may be determined by the 2018 statewide elections in Ohio. While it is unlikely to be a key campaign issue, the results may have significant ramifications for implementation. Asked about the outgoing governor's role in implementation, "Kasich doesn't care. It's [the MML] a gnat flying over his head, and he just wants to whack it away. He's not a true believer [in the policy]" (IV 3). Ohio's Medical Marijuana Control Program may not take off if this trend continues, or if the newly elected administration has similar sentiments. This process serves as a reminder of classic government truths - institutions matter and elections have consequences. Both are prescient in the case of Ohio's medical marijuana program. 


\section{TABLES}

Table 1: Mentions of Medical Marijuana with specific public health issues (1995-2017)

\begin{tabular}{|l|c|c|c|}
\hline $\begin{array}{l}\text { Search terms } \\
\text { HLEAD(medic! w/5 marijuana) }\end{array}$ & $\begin{array}{c}\text { New York } \\
\text { Times }\end{array}$ & $\begin{array}{c}\text { Washington } \\
\text { Post }\end{array}$ & $\begin{array}{c}\text { Dayton Daily } \\
\text { News }\end{array}$ \\
\hline Cancer & 199 & 204 & 40 \\
\hline HIV or AIDS & 160 & 176 & 14 \\
\hline PTSD or TBI or traumatic & 18 & 45 & 6 \\
\hline Seizure or epilepsy & 73 & 94 & 14 \\
\hline Opioid or opiate or heroin & 76 & 124 & 25 \\
\hline
\end{tabular}

${ }^{a}$ Syntax used in LexisNexis search.

Table 2: Features of MMLs by US Region

\begin{tabular}{|c|c|c|c|c|}
\hline & West & Northeast $^{\mathrm{a}}$ & Midwest & South \\
\hline $\begin{array}{c}\text { Number of state } \\
\text { with MMLs }\end{array}$ & 10 & 12 & 4 & 4 \\
\hline $\begin{array}{c}\text { Average year of } \\
\text { adoption }\end{array}$ & 2001 & 2010 & 2014 & 3 \\
\hline $\begin{array}{c}\text { Number of } \\
\text { medicalized } \\
\text { programs }\end{array}$ & 0 & $4^{\mathrm{b}}$ & 3 & 1 \\
\hline $\begin{array}{c}\text { MML passed by } \\
\text { Initiative }\end{array}$ & 8 & 2 & 1 & \\
\hline
\end{tabular}

${ }^{a}$ Author used U.S. Census regional codes for guidance but included DE, MD, and DC in Northeast Region because they have more in common with Eastern Seaboard states than other southern adopters $\mathrm{AR}, \mathrm{FL}, \mathrm{OK}$, and WV.

${ }^{\mathrm{b}}$ Williams et al. (2016) did not include NH and MA in their final analysis. 
FIGURES

Figure 1: States with Comprehensive Medical Marijuana Laws (1996-2018)

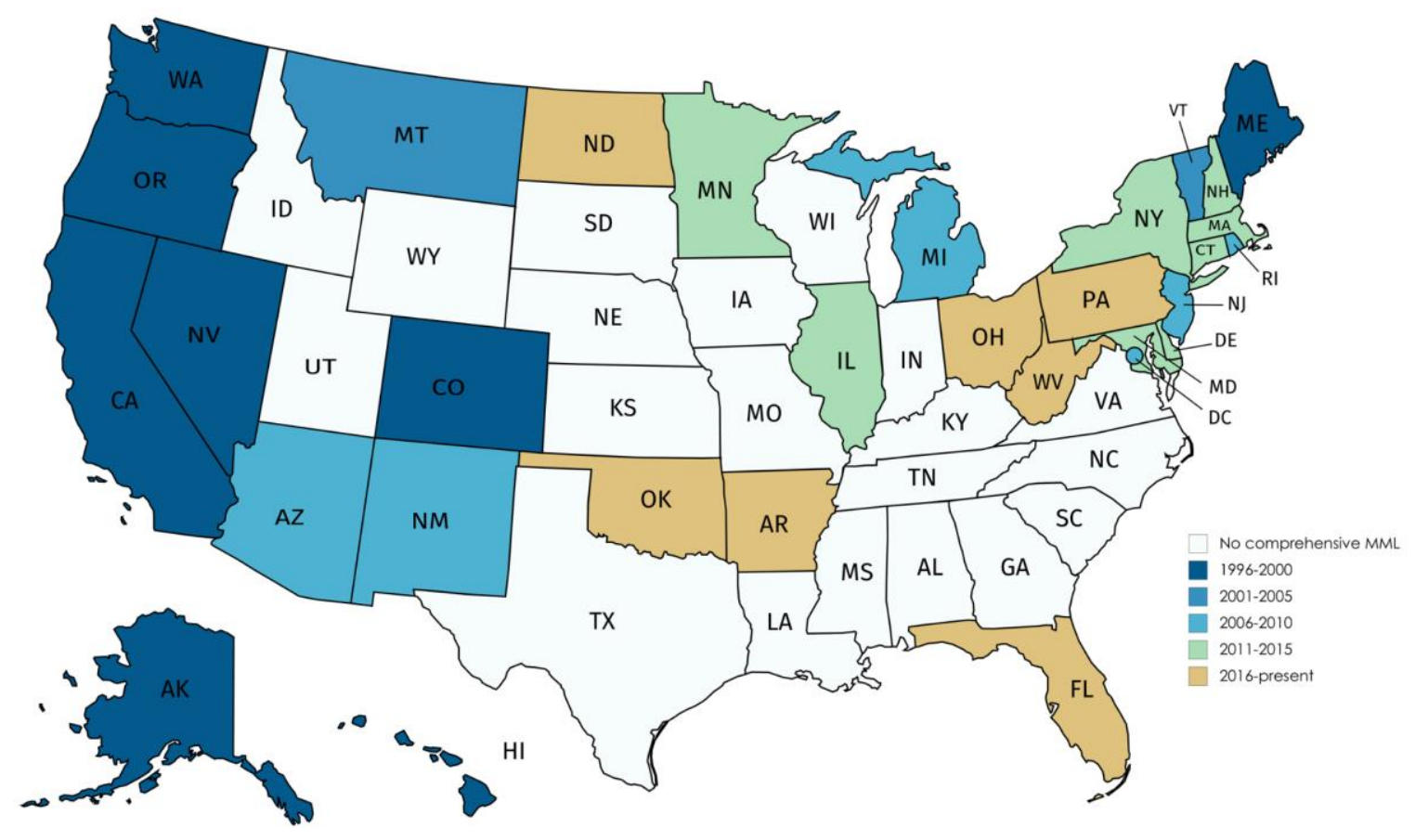


Figure 2: Mentions of Medical Marijuana in The New York Times with specific public health issues (1996-2017)
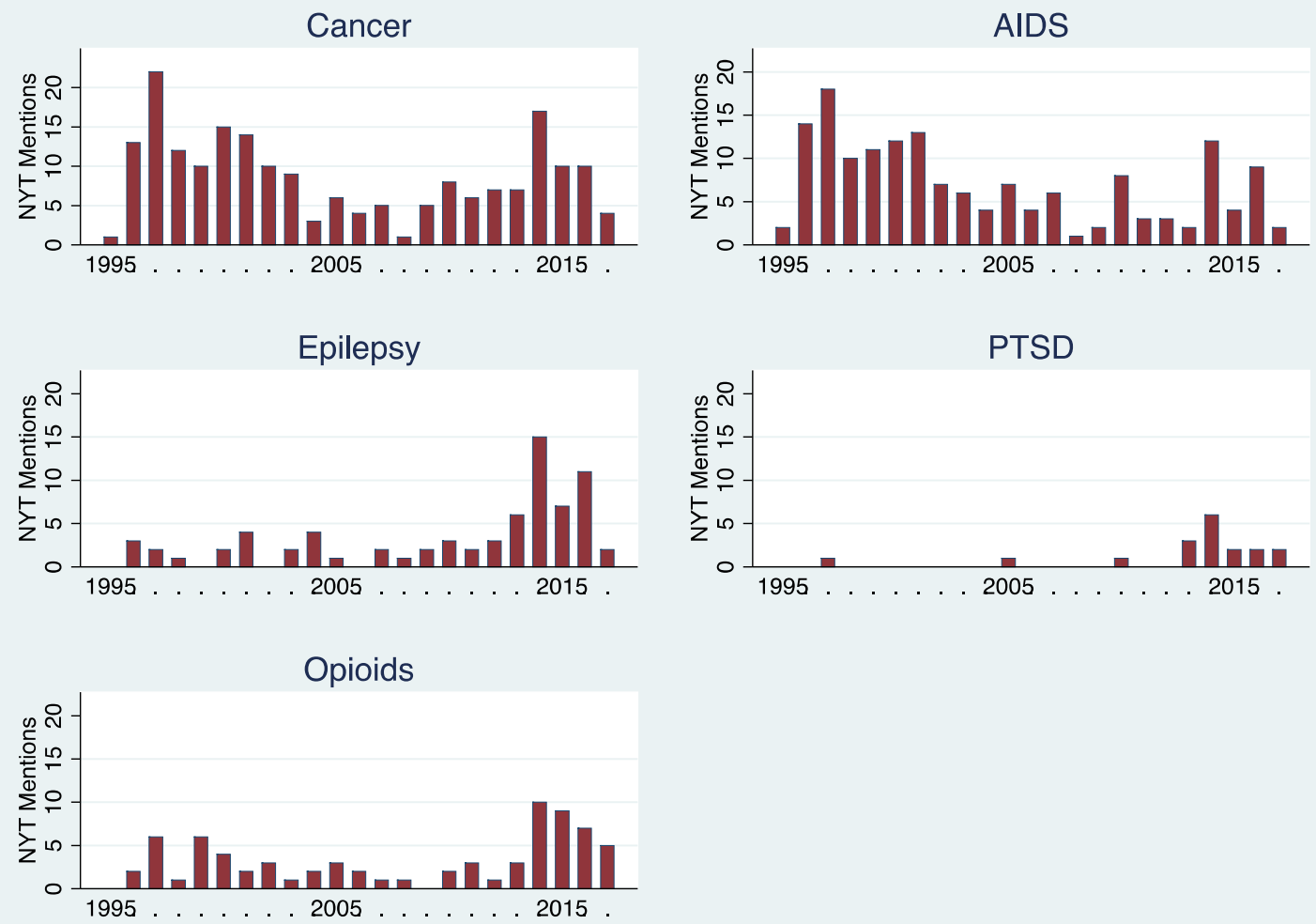
Figure 3: Mentions of Medical Marijuana in the Dayton Daily News with specific public health issues (1996-2017)
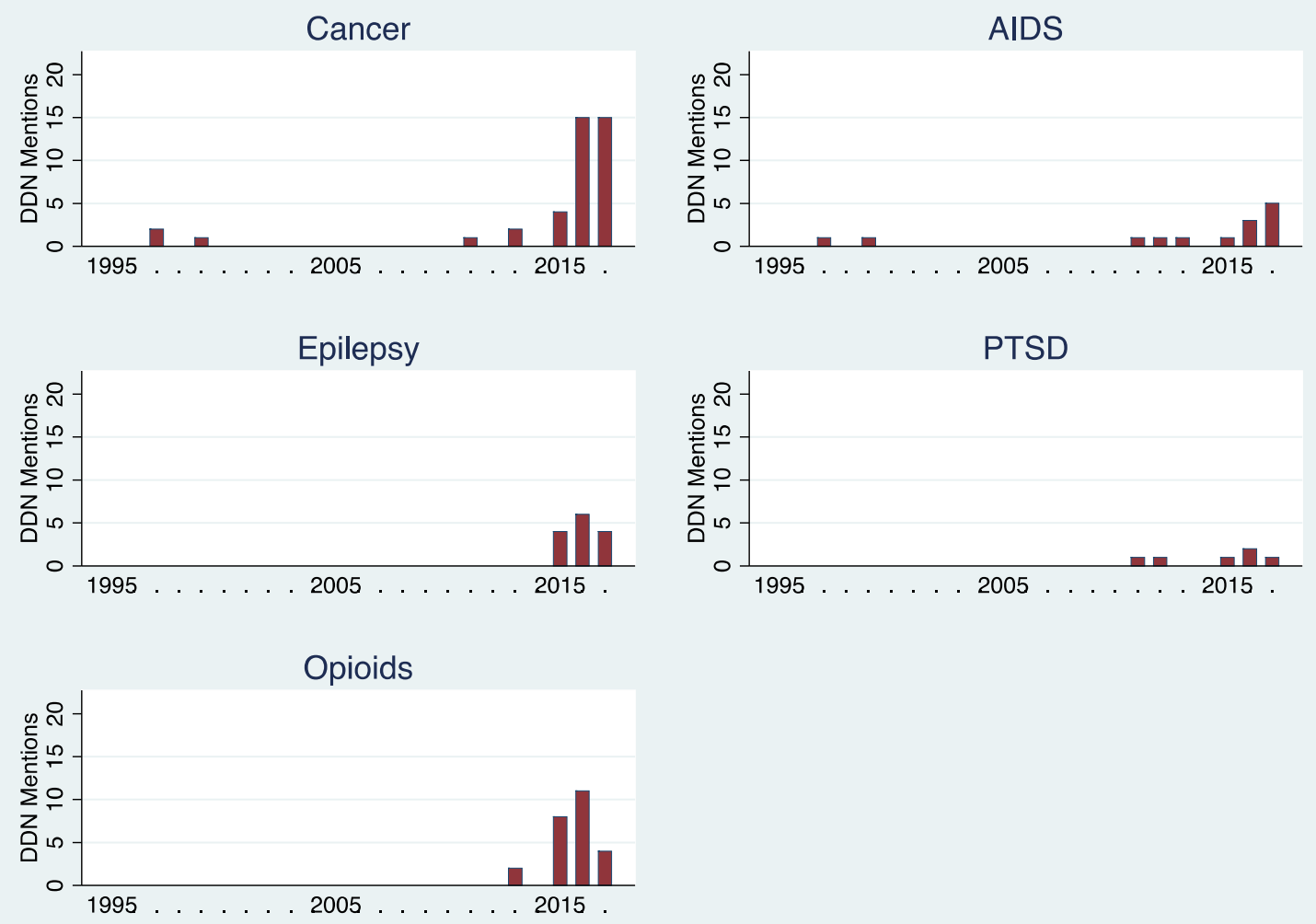
Figure 4: Number of qualifying conditions listed in MML over time.

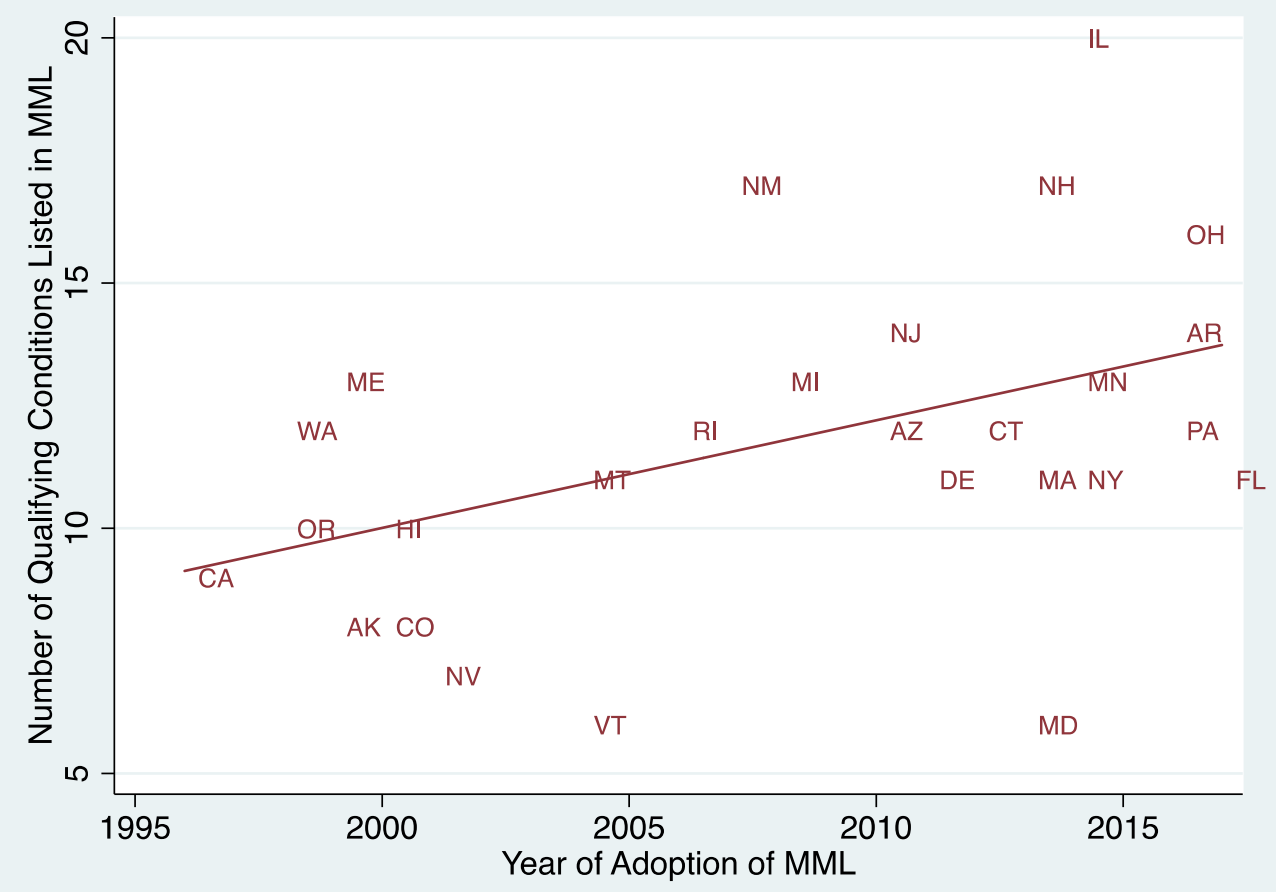

Note: Based on dataset constructed by Klieger et al. (2017)

Figure 1: Ohio Medical Marijuana Control Program - Status of Implementation (July 2018)

\begin{tabular}{|c|c|c|c|}
\hline Cultivating & Processing & Testing & Dispensing \\
\hline $\begin{array}{l}\text { Cultivators will plant } \\
\text { and grow marijuana } \\
\text { from seed to plant (3-4 } \\
\text { month long process). } \\
31 \text { Level I and II } \\
\text { cultivators have } \\
\text { received provisional } \\
\text { licenses. } \\
\text { Of the } 31 \text {, only } 1 \text { has } \\
\text { been allowed to start } \\
\text { growing as others wait } \\
\text { on final inspections. } \\
\\
\text { Many cultivators have } \\
\text { applied for processing } \\
\text { licenses. }\end{array}$ & $\begin{array}{l}\text { Processors will create } \\
\text { products out of } \\
\text { cultivated marijuana } \\
\text { including tinctures, } \\
\text { oils, and edibles. } \\
\text { State received } 104 \\
\text { applications in } \\
\text { December } 2017 \text { and } \\
\text { awarded } 40 \text { provisional } \\
\text { licenses. } \\
\text { No applicants have } \\
\text { been awarded full } \\
\text { licenses nor have } \\
\text { access to cultivated } \\
\text { plants. }\end{array}$ & $\begin{array}{l}\text { Testing labs will ensure } \\
\text { that products meet } \\
\text { certain guidelines. } \\
\text { Two testing labs have } \\
\text { been established at } \\
\text { Central State } \\
\text { University and Hocking } \\
\text { Technical College. } \\
\text { Ohio Department of } \\
\text { Commerce is } \\
\text { considering additional } \\
\text { sites. }\end{array}$ & $\begin{array}{l}\text { Dispensaries will serve } \\
\text { as the locations where } \\
\text { registered patients and } \\
\text { caregivers can purchase } \\
\text { cannabis products. } \\
\text { The board approved } 56 \\
\text { sites for provisional } \\
\text { dispensary licenses (out } \\
\text { of } 376 \text { applications). } \\
\text { Approved sites have six } \\
\text { months to meet all } \\
\text { requirements. }\end{array}$ \\
\hline
\end{tabular}

NOTE: Data from Borchardt (2018) and Simmons (2018). 


\begin{abstract}
APPENDIX

\section{Elite Interviews Protocol}

In order to better understand the adoption of and design of Ohio's MML I reached out to several organizations. In particular, I looked for organizations that were active in the legislation according to press reports (Public Relations in Table A1). Next, I reached out to those organizations via email or social media. Surprisingly, some organizations were more responsive to social media rather than email requests.
\end{abstract}

Table A1 shows the three different approaches. The outreach category includes public figures and organizations that I reached out to with no internal contacts. The personal contacts category includes individuals that I was connected with through another professional contact or already had a professional relationship with. Finally, many of the interviewees would make recommendations during our interview. In those cases, I was introduced to the contact via email. The names in bold correlate to how each is labeled in the text.

Of the 11 individuals or groups that I reached out to, I successfully completed an interview with six of them. Unsurprisingly, active legislators appeared most reluctant (or too busy) to agree to an interview. While each of the interview subjects approved of using their name and title, I decided to use titles and labels as shorthand and to follow conventions in the academic literature (Mosley, 2013). 
Table A2: Interview Protocol

\begin{tabular}{|c|c|c|}
\hline Interviewee & Status & Source \\
\hline \multicolumn{3}{|l|}{ Strategy 1: Outreach } \\
\hline Legislator 1 (retired) & $\begin{array}{l}\text { Agreed to interview (March 1, 2018), } \\
\text { Responded to follow-up request } \\
\text { (March 13, 2018). Did not reply to } \\
\text { emailed questions. }\end{array}$ & Facebook and email \\
\hline $\begin{array}{l}\text { Legislator } 2 \text { (active) - } \\
\text { Proponent }\end{array}$ & No response (March 6, 2018) & Legislator's Website \\
\hline $\begin{array}{l}\text { Legislator } 3 \text { (active) - } \\
\text { Opponent }\end{array}$ & No response (March 8, 2018) & Twitter \\
\hline $\begin{array}{l}\text { Pro-Medical Marijuana } \\
\text { Interest Group 1 - Legal } \\
\text { Counsel } 1 \\
\text { IV } 1\end{array}$ & $\begin{array}{l}\text { Agreed to interview (February } 27, \\
\text { 2018), Interview conducted by phone } \\
\text { on February } 28,2018\end{array}$ & $\begin{array}{l}\text { Facebook and } \\
\text { organization website }\end{array}$ \\
\hline $\begin{array}{l}\text { Pro-Medical Marijuana } \\
\text { Interest Group } 2 \text { - Director } \\
\text { IV } 5\end{array}$ & $\begin{array}{l}\text { Agreed to interview (February 24, } \\
\text { 2018), Interview scheduled (March 22, } \\
\text { 2018) }\end{array}$ & $\begin{array}{l}\text { Organization } \\
\text { Website }\end{array}$ \\
\hline $\begin{array}{l}\text { Anti-Medical Marijuana } \\
\text { Interest Group }\end{array}$ & No response (March 8, 2018) & $\begin{array}{l}\text { Organization } \\
\text { Website }\end{array}$ \\
\hline \multicolumn{3}{|l|}{$\begin{array}{l}\text { Strategy 2: Personal } \\
\text { Contacts }\end{array}$} \\
\hline $\begin{array}{l}\text { Journalist } \\
\text { IV } 2\end{array}$ & $\begin{array}{l}\text { Agreed to interview (February 28, } \\
\text { 2018). Emailed responses to my } \\
\text { questions (March 1, 2018) }\end{array}$ & Email \\
\hline $\begin{array}{l}\text { Consultant }- \text { Responsible } \\
\text { Ohio and marijuana industry } \\
\text { IV } 3\end{array}$ & $\begin{array}{l}\text { Agreed to interview (March 5, 2018), } \\
\text { conducted interview (March 7, 2018). }\end{array}$ & Email \\
\hline \multicolumn{3}{|l|}{$\begin{array}{l}\text { Strategy 3: } \\
\text { Recommendations }\end{array}$} \\
\hline Legislator 2 (active) & No response (March 6, 2018) & Legislator's Website \\
\hline $\begin{array}{l}\text { Pro-Medical Marijuana } \\
\text { Interest Group 1 - Legal } \\
\text { Counsel } 2 \\
\text { IV } 4\end{array}$ & $\begin{array}{l}\text { Agreed to interview (March 1, 2018), } \\
\text { Conducted interview (March 9, 2018) }\end{array}$ & $\begin{array}{l}\text { Personal contact } \\
\text { from legal counsel } 1\end{array}$ \\
\hline $\begin{array}{l}\text { Co-Founder and CEO of } \\
\text { medical marijuana cultivator } \\
\text { and distributor }\end{array}$ & $\begin{array}{l}\text { Agreed to call in for interview (March } \\
8,2018 \text { ), did not call on two } \\
\text { subsequent attempts (March 15, } 2018 \\
\text { and March 19, 2018). }\end{array}$ & Company Website \\
\hline
\end{tabular}




\section{News Attention Analysis}

Using LexisNexis Academic, I search for articles that include "medical marijuana" in the headline and lead of articles and include references to key conditions that are treated with medical marijuana. Table 1 shows the search terms and the number of returns from The New York Times, the Dayton Daily News, and The Washington Post. I only report data for The New York Times and Dayton Daily News in the main text. While articles were collected from 1975 onward, the mentions are sparse until the early 1990s. Figures 1 and A1 show trends from 1995 onward, the same period when modern MMLs were first adopted.

The results from The Washington Post are collected to further validate the NYT measure. The trends for both papers are generally the same, although it is worth noting that The Post ran several stories related to the NFL and opioids and the New York Times' spike in attention in 2014 is related to the state legislature in New York passing the law. Below is the syntax for each of the searches:

\section{HLEAD(medic! w/5 marijuana) AND (opioid or opiate or heroin)}

The command HLEAD returns articles that included marijuana and a stem of "medic" such as "medicinal", "medical", etc. The "w/5" command means it searches for these two terms located within five words of each other. For example, an article that discusses "marijuana used as medicine" would be returned under this search. The AND operator directs LexisNexis to only return articles with medical marijuana in the headline or lead that also include (opioid, opiate, or heroin). It is worth noting that the articles are not mutually exclusive. Articles that include multiple diagnoses are double-counted in the analysis. This feature should give strength to the measure. That is, it's not just that articles starting mentioning opiates as a condition that could be treated by medical marijuana, it's that many of these articles do not include the list of previous conditions such as HIV/AIDS/ PTSD/etc. We can assume this means that they are elevating the role of medical marijuana as it pertains to opiates/epilepsy/etc. compared to other conditions.

I considered other nonmedical ways in which the issue might be framed. For example, I searched for "“countercult!' OR 'hipp!' OR 'recreation!"” as well as "gateway" to determine the extent that nonmedical frames were used. These searches produced a few articles with no clear patterns. 
Figure A1 Mentions of Medical Marijuana in The Washington Post with specific public health issues (1996-2017)
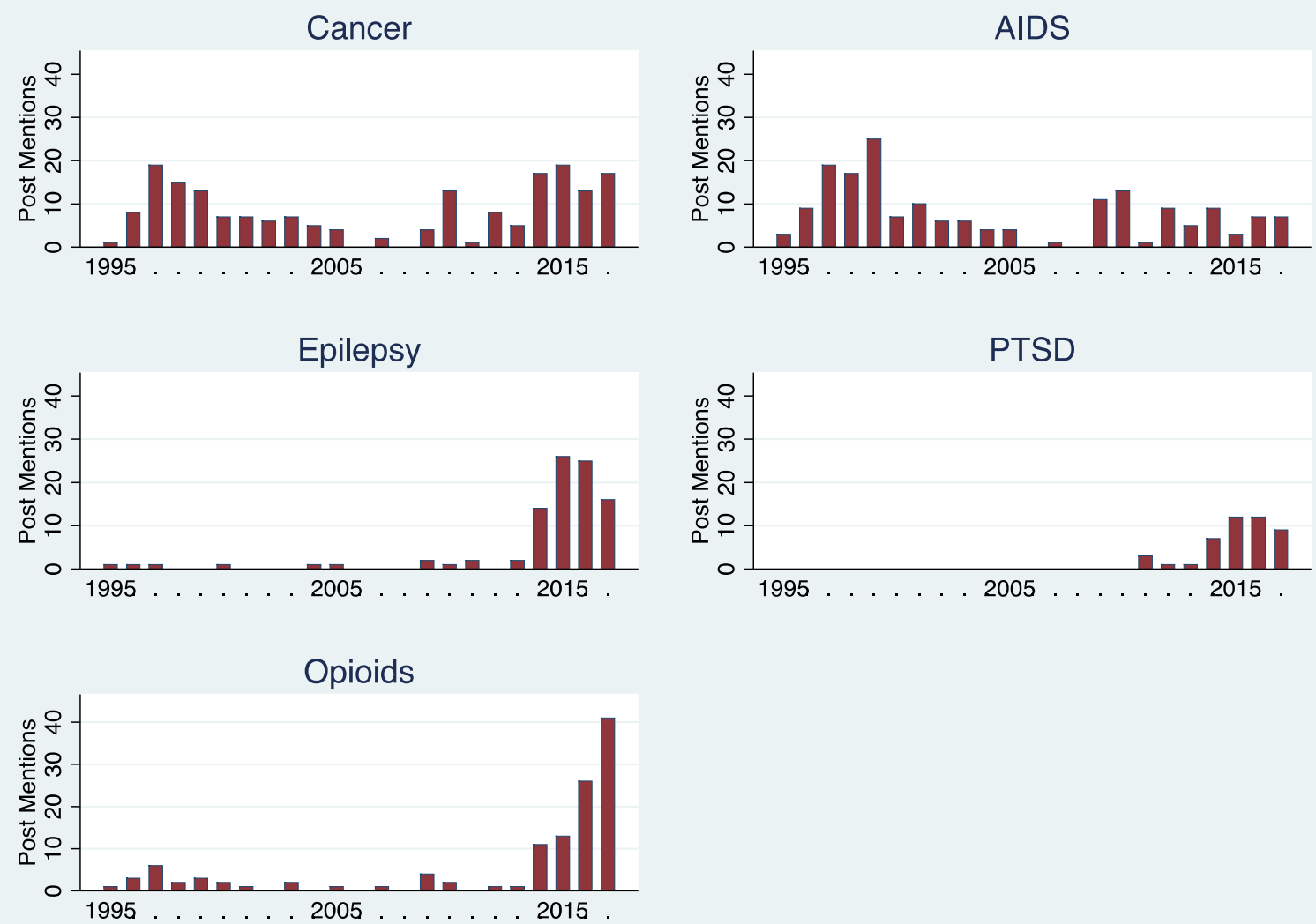


\section{REFERENCES}

Arceneaux, K. (2002). Direct Democracy and the Link between Public Opinion and State Abortion Policy. State Politics \& Policy Quarterly, 2(4), 372-387.

Bachhuber, M. A., Saloner, B., Cunningham, C. O., \& Barry, C. L. (2014). Medical cannabis laws and opioid analgesic overdose mortality in the United States, 1999-2010. JAMA Internal Medicine, 174(10), 1668-73.

Balmert, J. (2016a, May 20). Patients: We want medical marijuana. Cincinnati Enquirer. Retrieved from https://www.cincinnati.com/story/news/politics/2016/05/20/patients-wewant-medical-marijuana/83283248/

Balmert, J. (2016b, May 28). Marijuana Policy Project drops Ohio initiative. Cincinnati Enquirer. Retrieved from https://www.fool.com/investing/2016/05/28/will-ohios-medicalmarijuana-law-get-stiff-armed-b.aspx

Berke, J. (2018, April 20). Top Democrats have introduced a number of bills to push for the federal legalization of marijuana. Business Insider. Retrieved from https://www.businessinsider.com/marijuana-justice-act-marijuana-legalization-billintroduced-in-house-2018-1

Berry, F. S., \& Berry, W. D. (1990). State Lottery Adoptions as Policy Innovations: An Event History Analysis. The American Political Science Review, 84(2), 395-415.

Berry, W. D., \& Baybeck, B. (2005). Using Geographic Information Systems to Study Interstate Competition. American Political Science Review, 99(04), 505-519.

Birkland, T., \& Waterman, S. (2008). Is federalism the reason for policy failure in Hurricane Katrina? Publius, 38(4), 692-714.

Bischoff, L. A. (2017, December 14). Controversy, legal threats mar Ohio's medical pot launch. Dayton Daily News. Retrieved from https://www.mydaytondailynews.com/news/state-regional-govt--politics/controversy-legal-threats-mar-ohio-medical-potlaunch/dnUxdvTzl0nJH7bLY03KMM/

Boehmke, F. J., \& Witmer, R. (2004). Disentangling Diffusion: The Effects of Social Learning and Economic Competition on State Policy Innovation and Expansion. Political Research Quarterly, 57(1), 39-51. https://doi.org/10.1177/106591290405700104

Bonn-Miller, M. O., Babson, K. A., \& Vandrey, R. (2014). Using cannabis to help you sleep: Heightened frequency of medical cannabis use among those with PTSD. Drug and Alcohol Dependence, 136, 162-165. https://doi.org/10.1016/J.DRUGALCDEP.2013.12.008

Borchardt, J. (2015, December 14). Issue 3 backers spent $\$ 21.5$ million on failed Ohio marijuana legalization amendment. Cleveland Plain Dealer. Retrieved from https://www.cleveland.com/open/index.ssf/2015/12/issue_3_backers_spent_215_mill.html

Borchardt, J. (2016a, January 22). 5 ways new medical marijuana initiative changes the game in Ohio: Analysis. Cleveland Plain Dealer. Retrieved from https://www.cleveland.com/open/index.ssf/2016/01/5_ways_new_medical_marijuana_initia tive_changes_the_game_in_ohio_analysis.html

Borchardt, J. (2016b, April 6). Could medical marijuana solve Ohio's opioid problem. Cleveland Plain Dealer. Retrieved from https://www.cleveland.com/open/index.ssf/2016/05/could_medical_marijuana_solve.html

Borchardt, J. (2016c, June 8). Gov. John Kasich signs medical marijuana bill into law. Cleveland Plain Dealer. Retrieved from http://www.cleveland.com/open/index.ssf/2016/06/gov_john_kasich_signs_medical.html 
Borchardt, J. (2018, June 8). Ohio's first medical marijuana dispensary licenses awarded: See the list. Cleveland Plain Dealer. Retrieved from https://www.cleveland.com/metro/index.ssf/2018/06/ohios_first_medical_marijuana.html

Bradford, A. C., \& Bradford, W. D. (2016). Medical marijuana laws reduce prescription medication use in Medicare Part D. Health Affairs, 35(7), 1230-1236. https://doi.org/10.1377/hlthaff.2015.1661

Breitenbach, S. (2015, October 19). Many states still grapple with regulating medical marijuana. Pew Stateline. Retrieved from http://www.pewtrusts.org/en/research-andanalysis/blogs/stateline/2015/10/19/many-states-still-grapple-with-regulating-medicalmarijuana

Cha, A. E. (2014, March 2). "Mommy lobby" emerges as a powerful advocate for medical marijuana. Washington Post. Retrieved from https://www.washingtonpost.com/national/health-science/mommy-lobby-emerges-as-apowerful-advocate-for-medical-marijuana-for-children/2014/03/02/296ad1e2-9a38-11e3b88d-f36c07223d88_story.html?utm_term=.44800bc8f4f4

Chapman, S. A., Spetz, J., Lin, J., Chan, K., \& Schmidt, L. A. (2016). Capturing heterogeneity in medical marijuana policies: A taxonomy of regulatory regimes across the United States. Substance Use and Misuse, 5(9), 1174-1184.

Devinsky, O., Cilio, M. R., Cross, H., Fernandez-Ruiz, J., French, J., Hill, C., ... Friedman, D. (2014). Cannabidiol: Pharmacology and potential therapeutic role in epilepsy and other neuropsychiatric disorders. Epilepsia, 55(6), 791-802.

Ellerbrock, J. (2018, March 1). Lima lifts marijuana moratorium, too late to matter? The Lima News. Retrieved from https://www.limaohio.com/news/288098/lima-lifts-marijuanamoratorium-too-late-to-matter

Garbe, W., \& Bischoff, L. A. (2018, May 17). Recreational marijuana closer to Ohio ballot - but lots of work ahead. Dayton Daily News. Retrieved from https://www.daytondailynews.com/news/state--regional-govt--politics/recreationalmarijuana-closer-ohio-ballot-but-lots-work-ahead/j1RD3swkMcSvX2Zaff3q5K/

Gerber, E. R. (1996). Legislative Response to the Threat of Popular Initiatives. American Journal of Political Science, 40(1), 99-128.

Gerber, E. R. (1999). The populist paradox: interest group influence and the promise of direct legislation. Princeton, N.J: Princeton University Press.

Goldberg, C. (1996, October 30). Medical marijuana use winning backing. New York Times. Retrieved from http://www.nytimes.com/1996/10/30/us/medical-marijuana-use-winningbacking.html

Graham, D. A. (2015, November 3). Why Did Ohio's Marijuana-Legalization Push Fail? The Atlantic. Retrieved from https://www.theatlantic.com/politics/archive/2015/11/where-didohios-marijuana-legalizers-go-wrong/414061/

Gray, V. (1973). Innovation in the States: A Diffusion Study. American Political Science Review, 67(04), 1174-1185.

Hall, W., West, R., Marsden, J., Humphreys, K., Neale, J., \& Petry, N. (2018). It is premature to expand access to medicinal cannabis in hopes of solving the US opioid crisis. Addiction, 113(6), 987-988.

Hannah, A. L., \& Mallinson, D. J. (2018). Defiant Innovation: The Adoption of Medical Marijuana Laws in the American States. Policy Studies Journal, 46(2), 402-423.

Heininger, C. (2010, January 18). N.J. medical marijuana law is signed by Gov. Corzine. 
NJ.Com2. Retrieved from

https://www.nj.com/news/index.ssf/2010/01/medical_marijuana_law_to_take.html

Henry, T. (2016, February 12). Area patients praise marijuana benefits. Toledo Blade. Retrieved from http://www.toledoblade.com/Medical/2016/02/12/Area-patients-praise-marijuanabenefits.html

Higgs, R. (2015, April 6). Ohio voters favor legalizing marijuana, huge majority supports medical use, poll finds. Cleveland Plain Dealer. Retrieved from http://www.cleveland.com/open/index.ssf/2015/04/ohio_voters_favor_legalizing_m.html

Johnson, B. (2014, June 17). Christie says medical marijuana programs are "a front for legalization." NJ.Com. Retrieved from https://www.nj.com/politics/index.ssf/2014/06/christie_says_medical_marijuana_programs_ are_a_front_for_legalization.html

Jonsson, P. (2018, July 5). As war veterans enter the fray, stigma lessens around cannabis. Christian Science Monitor. Retrieved from https://www.csmonitor.com/USA/Society/2018/0705/As-war-vets-enter-the-fray-stigmalessens-around-cannabis

Karch, A. (2007). Emerging Issues and Future Directions in State Policy Diffusion Research. State Politics \& Policy Quarterly, 7(1), 54-80.

Kim, J. H., Santaella-Tenorio, J., Mauro, C., Wrobel, J., Cerdà, M., Keyes, K. M., ... Li, G. (2016). State Medical Marijuana Laws and the Prevalence of Opioids Detected Among Fatally Injured Drivers. American Journal of Public Health, 106(11), 2032-2037.

Kingdon, J. W. (1995). Agendas, Alternatives, and Public Policies (2nd ed.). Ann Arbor, MI: University of Michigan Press.

Klieger, S. B., Gutman, A., Allen, L., Pacula, R. L., Ibrahim, J. K., \& Burris, S. (2017). Mapping medical marijuana: State laws regulating patients, product safety, supply chains and dispensaries, 2017. Addiction.

Knox, T. (2017, May 23). Here's a list of Ohio cities banning medical marijuana businesses. Retrieved July 22, 2018, from https://www.bizjournals.com/columbus/news/2017/05/23/heres-a-list-of-ohio-citiesbanning-medical.html

Lascher, E. L., \& Hagen, M. G. (1996). Gun behind the door? Ballot initiatives, state policies and public opinion. Journal of Politics, 58(3), 760.

Lax, J. R., \& Phillips, J. H. (2009). Gay Rights in the States: Public Opinion and Policy Responsiveness. American Political Science Review, 103(03), 367.

Livio, S. K. (2018, January 23). Phil Murphy moves to expand access to medical marijuana in New Jersey. NJ.Com. Retrieved from https://www.nj.com/politics/index.ssf/2018/01/hold_murphy_expands_medical_marijuana_ program_adds.html

Lopez, G. (2018, April 30). Medical marijuana may help combat the opioid crisis. But there are better solutions. Vox. Retrieved from https://www.vox.com/policy-andpolitics/2018/4/30/17302692/opioid-epidemic-medical-marijuana-painkiller

Lupia, A., \& Matsusaka, J. G. (2004). Direct democracy: new approaches to old questions. Annual Review of Political Science, 7(1), 463-482.

Maa, E., \& Figi, P. (2014). The case for medical marijuana in epilepsy. Epilepsia, 55(6), 783786. 
Matsusaka, J. G. (2004). For the many or the few: The initiative, public policy, and American democracy. Chicago: University of Chicago Press.

Matsusaka, J. G. (2014). Disentangling the direct and indirect effects of the initiative process. Public Choice, 160(3-4), 345-366.

Molotch, H., \& Lester, M. (1975). Accidental News: The Great Oil Spill as Local Occurrence and National Event. American Journal of Sociology, 81(2), 235-260.

Mosley, L. (Ed.). (2013). Interview research in political science. Ithaca, NY: Cornell University Press.

Nash, J. (2018, May 15). NJ medical marijuana program could double the number of patients. Northjersey.Com. Retrieved from https://www.northjersey.com/story/news/newjersey/2018/05/15/state-says-nj-medical-marijuana-program-expanding/611272002/

Pacula, R. L., Powell, D., Heaton, P., \& Sevigny, E. (2014). Assessing the Effects of Medical Marijuana Laws on Marijuana Use: The Devil is in the Details. Journal of Policy Analysis and Management, 34(1), 7-31.

Pacula, R. L., \& Sevigny, E. L. (2014). Marijuana Liberalization Policies: Why We Can't Learn Much from Policy Still in Motion. Journal of Policy Analysis and Management, 33(1), 212221.

Patterson, J. (2018, June 28). Marijuana dispensary sparks concerns. The Marietta Times. Retrieved from http://www.mariettatimes.com/news/2018/06/marijuana-dispensary-sparksconcerns/

Phillips, J. H. (2008). Does the Citizen Initiative Weaken Party Government? State Politics \& Policy Quarterly, 8(2), 127-149.

Pickert, K. (2014, September 5). Finally, Some Hard Science on Medical Marijuana for Epilepsy Patients. Time. Retrieved from http://time.com/3264691/medical-marijauna-epilepsyresearch-charlottes-web-study/

Sandy, E. (2017, April 19). What You Need to Know About Ohio's Medical Marijuana Law, In Efffect for Seven Months and Changing Every Day. Cleveland Scene. Retrieved from https://www.clevescene.com/cleveland/what-you-need-to-know-about-ohios-medicalmarijuana-law-in-effect-for-seven-months-and-changing-every-day/Content oid $=6827613$

Schneider, A., \& Ingram, H. (1993). Social construction of target populations: Implications for politics and policy. American Political Science Review, 87(2), 334-337.

Shi, Y. (2017). Medical marijuana policies and hospitalizations related to marijuana and opioid pain reliever. Drug and Alcohol Dependence, 173, 144-150.

Shoup, C. (2018, June 11). Police chief does not expect "reefer madness." The News-Messenger. Retrieved from https://www.thenews-messenger.com/story/news/crime/2018/06/11/policechief-does-not-expect-reefer-madness-medical-marijuana/682130002/

Simmons, B. (2018, July 20). Understanding Ohio's medical marijuana hold up. WKYC. Retrieved from https:/www.wkyc.com/article/news/health/understanding-ohios-medicalmarijuana-hold-up/95-575964821

Starke, P. (2013). Qualitative Methods for the Study of Policy Diffusion: Challenges and Available Solutions. Policy Studies Journal, 41(4), 561-582.

Stewart, C. (2018, June 10). Neighors: Medical marijuana shops will attract problems. Dayton Daily News. Retrieved from https://www.daytondailynews.com/news/neighbors-medicalmarijuana-shops-will-attract-problems/ov0LJ5LzHfcly7c4sMr9jM/ 
Tucker, R. (2018a, May 15). State grader tossed personal notes after helping to score medical marijuana applications. Cincinnati Enquirer. Retrieved from https://www.cincinnati.com/story/money/2018/05/15/marijuana-program-grader-tossedpersonal-notes/609618002/

Tucker, R. (2018b, July 17). Ohio's medical marijuana patient registry put on hold. Cincinnati Enquirer. Retrieved from https://www.cincinnati.com/story/money/2018/07/17/medicalmarijuana-patient-registry-put-hold/791423002/

Volden, C. (2017). Policy Diffusion in Polarized Times: The Case of the Affordable Care Act. Journal of Health Politics, Policy and Law, 42(2), 363-375.

Volpenhein, S. (2017, October 31). Medical marijuana sparks debate at special council meeting. The Marion Star. Retrieved from https://www.marionstar.com/story/news/local/2017/10/31/medical-marijuana-sparksdebate-special-council-meeting/817215001/

Walker, J. L. (1969). The Diffusion of Innovations among the American States. The American Political Science Review, 63(3), 880-899.

Werner, C. A. (2001). Medical marijuana and the AIDS crisis. Journal of Cannabis Therapeutics, 1(3-4), 17-33.

Whyte, L. E. (2015, June). Ohio Legislature Strikes Back Against Marijuana Legalization Bid. Time. Retrieved from http://time.com/3943153/marijuana-legalization-ohio-legislature/

Wilkerson, R. G., Kim, H. K., Windsor, T. A., \& Mareiniss, D. P. (2016). The Opioid Epidemic in the United States. Emergency Medicine Clinics of North America, 34(2), e1-e23.

Williams, A. R., Olfson, M., Kim, J. H., Martins, S. S., \& Kleber, H. D. (2016). Older, less regulated medical marijuana programs have much greater enrollment rates than newer "medicalized" programs. Health Affairs, 35(3), 480-488.

Williams, M. (2018, February 18). Many Ohio employers likely to bar medical-marijuana use. Columbus Dispatch. Retrieved from http://www.toledoblade.com/local/2018/03/19/Application-process-begins-for-Ohiodoctors-to-prescribe-medical-marijuana.html

Wilson, R. (2018, June 6). Beavercreek: Fighting marijuana biz could cost "millions of dollars." Dayton Daily News. Retrieved from https://www.mydaytondailynews.com/news/beavercreek-fighting-marijuana-biz-could-costmillions-dollars/6vTOw4FKb8wZchotSD5ywL/ 


\section{ENDNOTES}

${ }^{1}$ The author consulted with their university's Institutional Review Board about the interviews. The IRB ruled that this research is not considered human subjects research under the Common Rule. Therefore, no further action was necessary.

${ }^{2}$ NCSL - http://www.webcitation.org/6qv4nUpXN

${ }^{3}$ From NCSL web page accessed 9 February 2018 - http://www.webcitation.org/6qv4nUpXN

${ }^{4}$ NCSL Ballot Measures Database accessed 10 March 2018 http://www.ncsl.org/research/elections-and-campaigns/ballot-measures-database.aspx

${ }_{5}^{5}$ Ohio General Assembly proceedings available on The Ohio Channel, accessed on 2 March 2018. Transcribed by author. House - http://www.ohiochannel.org/video/ohio-house-ofrepresentatives-5-10-2016; Senate - http://www.ohiochannel.org/video/ohio-senate-5-25-2016part-2

${ }^{6}$ LexisNexis Academic does not include other regional papers in Ohio such as the Cleveland Plain Dealer or Columbus Dispatch. While combining these papers would be ideal, I chose to analyze the Dayton Daily News in the same program as the analysis of the NYT and Washington Post. Admittedly, the fact that Dayton is considered one of the most hard hit cities by the epidemic, the framing of opiates might be higher than if averaged out with other Ohio regional papers.

${ }^{7}$ Surprisingly, I found no evidence that papers in Southeast Ohio were making the same connection. In fact, the passage of the policy received little coverage. This may be due to the papers working with fewer resources. I also cannot rule that these papers might have included articles from other publications like the Associated Press that made these connections.

${ }^{8}$ It is important to emphasize the laws were coded as they existed on that date. Several state laws have been revised. For example, California passed the first medical marijuana law in 1996 but this law was amended in 2003. When discussing temporal trends in the content of laws, I use the year in which the law was last updated rather than when it was first passed. West Virginia and Oklahoma passed laws after the creation of the dataset and are not included in the dataset http://www.webcitation.org/6xWZCTuBf

${ }^{9}$ Ohio's law has not been coded for provisions on product safety

${ }^{10}$ Guidelines are available at https://medicalmarijuana.ohio.gov/patients-caregivers

${ }^{11}$ Florida is the only state that both restricts home cultivation and passed the law via initiative. 